\title{
KNOWLEDGE, ATTITUDES AND PRACTICES ON HIV PREVENTION AMONG SECONDARY SCHOOL STUDENTS IN BUKOBA RURAL, KAGERA REGION- TANZANIA
}

\author{
By Kamala B.A., Aboud S
}

\begin{abstract}
It is estimated that about 42 million people are living with HIV/AIDS worldwide. Among them $90 \%$ are from developing countries and more than $70 \%$ of them are found in Sub-Saharan Africa including Tanzania. About 4.8 million people are infected annually, $70 \%$ being women and 3 million are in Sub-Saharan Africa. Approximately 3 million people died from AIDS in 2003 worldwide. Documented data show that the reproductive age group is more vulnerable and thus an intervention is necessary in this age group.
\end{abstract}

Objectives: To assess knowledge, attitudes and practices on HIV preventive measures among secondary school students.

Settings: Bukoba district, Kagera region, Tanzania

Design: A cross sectional study was conducted in Bukoba rural district, Kagera region, in September 2005.

Methods: Multi-stage sampling technique was used to determine the study population and 364 students were interviewed using structured questionnaire.

Results: Our study findings showed that $93.7 \%$ of students knew how HIV is transmitted and $86.6 \%$ knew at least one method of HIV prevention. Students mentioned abstinence and faithfulness to one partner as best methods for HIV prevention. Despite the knowledge they have, very few students reported to have used condoms in their last sexual contacts. Radio was reported to be the major source of information even though information given was not satisfactory to most of the students. In addition, $50 \%$ of students reported to have experienced sex, the peak age of first sexual intercourse being 15 years.
Conclusion: Most of the students had an objective knowledge on HIV/AIDS transmission and prevention though their attitudes and practices were different.

Recommendation: Health education should be promoted among youth especially in rural areas. Reproductive health consequences of pre-marital sex should be explained to students to prevent complications of reproductive tract infections.

Correspondence to: Kamala, Benjamin A., P.O. Box 65001, Muhimbili University College of Health Sciences, School of Medicine. E-mail: kamala8085@yahoo.com Mob:+255-741-691-949.

\section{INTRODUCTION}

Acquired Immunodeficiency Syndrome (AIDS) was first described in the USA in 1981. Human Immunodeficiency Virus (HIV) was first isolated by the end of 1983. In Tanzania, the first case of AIDS was identified in 1983 - Kagera region. Since then AIDS has becomes a pandemic expanding in scope and magnitude. There are two types of HIV: HIV-1 is cosmopolitan while HIV-2 is found primarily in the West Africa. HIV-2 has only $40 \%$ of its protein identical to HIV-1 and is much less transmissible than HIV-1.

HIV is the cause of AIDS. It is a single stranded RNA virus belonging to the retroviridae family which cause a slow infection with long incubation period. It has a bar shaped core which is surrounded by an envelope containing virus specific glycoproteins (gp120 and gp41). It has three typical retroviral genes namely, gag, pol and env which encode for structural proteins. The gag gene encodes for internal core proteins important of which is p24 used in serological tests. Pol gene encodes for reverse transcriptase, integrase and protease. The env gene encodes for gp160 which is 
precursor of glycoproteins gp120 and gp41, the envelope glycoproteins.

HIV is one of the human lymphotrophic retroviruses preferentially infecting CD4 lymphocytes. Once it enters the human body, the gp120 binds to CD4 receptors and then gp120 interacts with chemokine receptors (CCR5, CXCR4 and fusin). The gp41 mediates fusion of viral envelope to cell membrane. After uncoating reverse transcriptase transcribes the RNA genome to double stranded DNA which integrates into the host cell DNA by integrase. Multiple copies of DNA can be integrated in the same DNA. Viral mRNA is transcribed from proviral DNA by host RNA polymerase, translated to several large proteins which are cleaved by viral encoded protease to form virion structural proteins namely reverse transcriptase, core proteins and two envelop glycoproteins. The virions assemble in the cytoplasm and are released by cell budding consequently causing cell death. The killing of CD4 lymphocytes results in the suppression of cell mediated immunity leading to high probability that the host will develop opportunistic infections such as tuberculosis, cryptococcosis, pneumocystosis and certain cancers such as lymphoma and Kaposi sarcoma

Transmission is mainly by unprotected sexual contacts $(82.1 \%)$, mother to child (antenatal, perinatal and postnatal), and transfer of infected blood. There are several methods to prevent HIV transmission, these include comprehensive education and campaign, safe sex by use of condoms, abstinence, faithfulness, safe blood transfusion and the use of antiretroviral drugs to prevent mother to child transmission (MTCT) of HIV. Condoms if properly used are $84 \%$ safe. Also safe sex not only prevents HIV transmission but also other STI's which aggravate the transmission of HIV by 17 times ((NACP Surveillance Report 2003).

\section{MATERIALS AND METHODS}

A descriptive cross-sectional study was conducted in five secondary schools. Multi-stage sampling technique was used in order to obtain a representative sample. Five secondary schools named Katele, Iluhya, Hekima, Nyakato and Buyango were randomly selected. Then from each school students were randomly selected by using random tables. Structured questionnaires were used to collect the information.

\section{RESULTS}

The study population consisted of 364 students of which $61.0 \%$ were males and $39.0 \%$ were females. Out of these $28.8 \%$ form I students, $36.3 \%$ form II students, $19.8 \%$ form III students and $15.1 \%$ form IV students.

Most of the interviewees (93.7\%) knew how HIV/AIDS is transmitted. When respondents were asked about the method they knew on HIV transmission most of them mentioned sexual intercourse $(86.7 \%)$, piercing objects $(84.3 \%)$, blood transfusion $(75.5 \%)$ and very few mentioned MTCT (20.7\%).

Majority of the respondents, both males $(94.6 \%)$ and females $(94.4 \%)$ knew at least one method of HIV/AIDS prevention and very few of them $(5.5 \%)$ could not mention any method. Sixty nine percent $(69.0 \%)$ of respondents who knew how to prevent HIV/AIDS mentioned abstinence and faithfulness to single partner, $(48.0 \%)$ mentioned the use of condoms, $37 \%$ mentioned safe blood transfusion and few of them (19.4\%) mentioned avoidance of pregnancy for infected mothers. There was no significant difference by sex between methods mentioned for HIV prevention suggesting similar knowledge in both sexes. The best method mentioned by both male and female students was abstinence followed by being faithfulness as shown in the Table 1 below.

Table 1: Distribution of the best method for HIV prevention by sex

\begin{tabular}{|l|l|l|l|l|}
\hline \multicolumn{5}{|l|}{ BEST METHOD } \\
\hline SEX & Condom use (\%) & Abstinence (\%) & Faithfulness (\%) & Others (\%) \\
\hline MALE & $32(15.1)$ & $112(53.8)$ & $65(30.7)$ & $1(0.5)$ \\
\hline FEMALE & $22(16.4)$ & $71(53.0)$ & $39(21.1)$ & $2(1.5)$ \\
\hline TOTAL & $54(\mathbf{1 5 . 6})$ & $183(\mathbf{5 3 . 5})$ & $104(30.1)$ & $3(0.9)$ \\
\hline
\end{tabular}

Majority of the interviewees mentioned radio as the major source of the information as shown in Table 2 although most of them $(62.0 \%)$ needed much more information on HIV/AIDS and the preventive measures from other sources like health care workers, newspapers etc. 
Substantial number of students $(60.8 \%$ males and $71.8 \%)$ females did not agree with the condom use as the effective measure on HIV prevention. With respect to the level of education $39.4 \%$ of students were in form II $26.8 \%$ of students were in form III. Condom use for pregnancy prevention was the highly mentioned reason by all levels of education and sex (Table 3)

Table 2: Reasons given for not using condoms by level of education

\begin{tabular}{|l|l|l|l|l|l|}
\hline \multicolumn{5}{|c|}{ REASON GIVEN } & For avoiding \\
$\begin{array}{l}\text { LEVEL OF } \\
\text { (Form) }\end{array}$ & $\begin{array}{l}\text { Has pores } \\
(\%)\end{array}$ & $\begin{array}{l}\text { Not prostitutes } \\
\text { available } \\
(\%)\end{array}$ & $\begin{array}{l}\text { For } \\
\text { pregnancy } \\
(\%)\end{array}$ & $\begin{array}{l}\text { Tradition don't } \\
\text { allow } \\
(\%)\end{array}$ \\
\hline I & $14(46.7)$ & $3(10)$ & $14(46.7)$ & $0(0)$ & $4(13.8)$ \\
\hline II & $11(42.3)$ & $6(23.1)$ & $17(65.4)$ & $1(3.8)$ & $2(8.0)$ \\
\hline III & $14(56.0)$ & $1(4.0)$ & $17(68.0)$ & $1(4.0)$ & $2(8.1)$ \\
\hline IV & $4(30.8)$ & $3(23.1)$ & $6(46.2)$ & $0(0)$ & $0(0)$ \\
\hline TOTAL & $43(45.7)$ & $13(13.4)$ & $54(\mathbf{5 7 . 4})$ & $2(2.1)$ & $8 \quad(9.1)$ \\
\hline
\end{tabular}

More than half of the students $(53.6 \%)$ reported to have had penetrative sex. The proportion was much higher in males $(63.1 \%)$ than females $(38.6 \%)$. Half of the students $(52.5 \%)$ reported to have used condoms in their last sexual encounter. Condom use was high among female students (57.4\%) compared to male students $(49.3 \%)$

Our findings showed that as the level of education increases the proportion of students who had practiced sex increases from $40 \%$ in form I; to $52.8 \%$ in form II; to $54.6 \%$ in form III; to $78.2 \%$ in form IV. The peak age of the first sexual intercourse was 15 years $(23.7 \%)$, below this age many male students has higher proportion compared to female students (Table 9)

Table 3: Distribution of age at first sexual intercourse by sex

\begin{tabular}{|l|l|l|l|l|l|l|l|l|l|l|l|l|l|l|l|}
\hline & \multicolumn{10}{l|}{ Age at first sexual intercourse (\%) } & & \\
\hline Sex & 7 & 8 & 9 & 10 & 11 & 12 & 13 & 14 & $\mathbf{1 5}$ & 16 & 17 & 18 & 19 & 20 & Total \\
\hline Male & 2 & 2 & 4 & 6 & 4 & 10 & 6 & 10 & $\mathbf{3 4}$ & 21 & 20 & 15 & 2 & 4 & 140 \\
& 1.4 & 1.4 & 3.8 & 4.2 & 2.8 & 7.1 & 4.3 & 7.1 & $\mathbf{2 4 . 3}$ & 15.0 & 14.3 & 10.7 & 1.4 & 2.9 & 100 \\
\hline Female & 0 & 1 & 0 & 2 & 1 & 0 & 0 & 2 & $\mathbf{1 2}$ & 11 & 17 & 3 & 5 & 0 & 54 \\
& & 1.9 & & 3.7 & 1.9 & & & 3.7 & $\mathbf{2 2 . 2}$ & 20.0 & 31.5 & 5.6 & 9.3 & & 100 \\
\hline Total & 2 & 3 & 4 & 8 & 5 & 9 & 6 & 12 & $\mathbf{4 6}$ & 32 & 37 & 18 & 7 & 4 & 194 \\
& 0.9 & 1.5 & 2.0 & 4.0 & 2.5 & 4.6 & 3.1 & 6.2 & $\mathbf{2 3 . 7}$ & 16.5 & 19.1 & 9.3 & 3.6 & 2.1 & 100 \\
\hline
\end{tabular}

\section{DISCUSSION}

Assessing knowledge, attitudes and practices in HIV preventive cognitions is an important strategy in determining the gap in knowledge and its relationship with attitudes and practices. Our study findings showed that majority of students (93.7\%) knew how HIV is transmitted and very few of them $(6.3 \%)$ did not. Our findings are comparable to the findings of the study that was done in Moshi district ( Moshi S.J et al 2003) and other reports (NACP surveillance report 2003)

Higher proportion of students reported penetrative sex as the major mode of HIV transmission. This can be taken as a good start because it has been reported that about $78 \%$ of HIV infection are due to sexual contacts (NACP Surveillance report 2003).
So efforts in advocating safe sex among youth may yield good results, the basis being that if knowledge about HIV preventive measures including safe sex is imparted to students and if they abide to it then transmission by sexual contact will decrease.

Regarding modes of transmission many students mentioned sexual intercourse $(86.6 \%)$ piercing objects $(84.3 \%)$ and blood transfusion $(75.1 \%)$ and very few mentioned MTCT (20\%). This requires both governmental and Non-Governmental Organizations to emphasize on MTCT of HIV because the risks of infection to the new born by the infected mother are high.

It is documented that eighty percent $(80 \%)$ of youths in Africa had poor knowledge on HIV prevention (UNAIDS 2002). The increased 
knowledge may be the reason of a decrease in the overall prevalence of HIV-1 infection as documented previously (Kwesigabo G et al 1998).

Regarding the preventive measures they knew, most of the students mentioned abstinence and faithfulness to a single partner in large proportion $(69 \%)$ and condom use by $48 \%$. These findings suggest that health education on HIV preventive measures is still required because students should know all methods that they can use to protect themselves from infection. Emphasis should be put much on the use of condoms and safe blood transfusion.

Our findings showed that both male and female (53.8\% and 53.0\% respectively) students had good knowledge on the best method for HIV/AIDS prevention which was abstinence, faithfulness (30\%) followed by condom use which was lastly mentioned (15.9\%). This indicates a good knowledge among students on HIV/AIDS prevention. So campaigns on HIV/AIDS prevention should be maintained on this population.

Students indicated that they need much more information on HIV/AIDS. This calls for the educational bodies such as NACP, TACAIDS and other governmental and Non Governmental Organizations to try to promote the health education especially in rural areas which are hardly reached by education. Also, parents should be advised to talk to their children about HIV/AIDS openly as they are people who are very close to them.

Despite high knowledge on HIV/AIDS prevention they have, many students especially female students $(71.8 \%)$ did not agree that condom were effective to prevent HIV transmission. This was a misconception by the students and efforts to change this attitude should be taken so that transmission should be reduced.

More than half of students (53.6\%) reported to have had sex before. This proportion is higher than the study done in Zimbabwe which showed 40\% (Campbel B et al 1994) and 46\% condom use in Uganda (Abraham SC et al 1995). This is not an isolated finding because even another study done among commercial sexual workers demonstrated low condom use despite increased knowledge in HIV/AIDS prevention (Kwesigabo G et al 2003)..

Out of those who had sex only half of them mentioned to have used condoms. This study finding is higher compared to study done in the same region on sexual behavior (Lwihula $G$ et al 2000) which may be due to increased level of knowledge of the study population. Also this proportion is higher than the study done in Benin which revealed $36 \%$ condom use (Hounton $\mathrm{K}$ et al 1999).

The peak age at first sexual intercourse was fifteen years. This indicates that there is a lack of knowledge in the health consequences of practicing sex at much younger age and pre-marital sex. A lot of efforts to educate students to abstain is needed. All health consequences of early sexual intercourse should be explained to the young population to prevent morbidity and mortality.

\section{ACKNOWLEDGEMENTS}

I would like to thank the Office of the Dean of School Medicine for designing and supporting this program of students' research practice so as to promote and cultivate research habits among medical students interested to become researchers in the future.

My special thanks should go to Dr Said Aboud of the Department of Microbiology/Immunology, MUCHS for his excellent supervision throughout my study. I thank him for his moral and academic support. Whenever I needed him he was there for me.

Lastly but not least I thank my family for their advice, encouragement and every support that they have provided me whenever I needed.

\section{REFERENCES}

1. Abraham SC, Rubaale TK, Kipp W. HIVpreventive cognitions amongst secondary school students in Uganda. Health Educ Res 1995; 10 (2): 155-162.

2. Adih WK Alexander CS. Determinants of condom use to prevent HIV infection among youth in Ghana. J Adolesc Health 1999; 24 (1) 63-72.

3. Balyagati D, Luhamba D, Nnko S, Nyongo V, Schapink D. HIV/AIDS and STD Health Promotion in Tanzania fishing villages. AIDS STD Health Promot Exch 1995;2 (2): 3-7.

4. Benjamin JA. AIDS prevention for refugees, Aidscaptions 1996; 3(2):4-9. 
5. Campbell B, Mbizvo MT. Sexual behavior and HIV knowledge among adolescent boys in Zimbabwe. Centr Afr J Med 1994; 40 (9): 245-250.

6. Egger M, Ferrie J, Gorter A et al. HIV related knowledge, Attitude and practice among Managuan secondary school students. Bull Pan Am Health Organ 1993; 27 (4): 360-369.

7. Kwesigabo G, Killewo J, Godoy $\mathrm{C}$ et al. Decline in the prevalence of HIV-1 infection among young women in Kagera region of Tanzania. J Acquir Immune Defic Syndr Hum Retrovirol 1998; 17 (3): 262-268.

8. Kwesigabo G, Killewo JZ, Urasa W et al. Monitoring of HIV-1 infection prevalence and trends in the general population using pregnant women as sentinel population: 9 years experience from Kagera region of Tanzania, J Acquir Immune Defic Syndr 2000; 23 (5): 410-417.

9. Killewo J, Sandstrom A, Dahlgreen L, Wall S. Communicating with people about HIV infection risk as basis for planning interventions: lesson from Kagera region of Tanzania. Soc Sci Med 1997; 45 (2): 319 329.
10. Lugalla J, Emmelin M, Mutembei A et al. Social, cultural and sexual behavior determinants of observed decline in HIV infection trends: lessons from Kagera region, Tanzania. Soc Sci Med J 2004; 59 (1):185198.

11. Lwihula K, Dahlgren L, Killewo J, Sandstrom A. AIDS epidemic in Kagera region, Tanzania- the experience of local people. AIDS care 1993; 5 (3): 347-357.

12. Moshi SJ. Knowledge, perception, attitude and practices of safer sex among youth in Moshi Rural district, Kilimanjaro region. UDSM, MPH Dissertation 2003:pp35-36.

13. Shopper D, Doussantousse S, Ayiga $\mathrm{N}$ et al. Village based AIDS prevention in rural district in Uganda. Health policy plan J 1995; 10 (2): 171-180.

14. National AIDS Control Program Surveillance 2003. Ministry of Health, Tanzania Mainland. Report Number 17.

15. National AIDS Control Programme HIV/AIDS Surveillance of HIV and syphilis infections among antenatal clinic attendees 2003/04 Report. Ministry of Health, Tanzania Mainland. April 2005. 